\title{
AN UPDATE ON ADENOSINE A2A RECEPTORS AS DRUG TARGET IN PARKINSON'S DISEASE
}

\author{
Antoni Vallano ${ }^{1,2}$, Víctor Fernández-Dueñas ${ }^{2}$, Consuelo Pedrós ${ }^{1,2}$, Josep María
}

\section{Arnau $^{1,2}$ \& Francisco Ciruela ${ }^{2}$}

${ }^{1}$ Servei de Farmacologia Clínica, Hospital Universitari de Bellvitge-ICS, IDIBELL. ${ }^{2}$ Unitat de Farmacologia, Departament Patologia i Terapèutica Experimental, Facultat de Medicina, Universitat de Barcelona, L’Hospitalet de Llobregat, 08907 Barcelona, Spain.

Running title: $\mathrm{A}_{2 \mathrm{~A}} \mathrm{R}$ \& Parkinson's disease

Number of pages: 37

Abstract: 199 words

Main text: 4269 words

References: 67 references

Fig. legends: 131 words

Corresponding author: Francisco Ciruela, Ph.D.

University of Barcelona

Unitat de Farmacologia

Dept. de Patologia i Terapeutica Experimental

Facultat de Medicina (Campus de Bellvitge)

Pavelló de Govern, Av. Feixa Llarga, s/n

08907 L'Hospitalet del Llobregat, Barcelona, Spain

Tel: +34 (93) $4024280 /+34$ (93) 4035820

Fax: +34 (93) 4029082

E-mail: fciruela@ub.edu

Keywords: Adenosine $\mathrm{A}_{2 \mathrm{~A}}$ receptors; Parkinson's disease; GPCR oligomerization; Clinical trial; Istradefylline; Preladenant. 


\begin{abstract}
Adenosine receptors are $G$ protein-coupled receptors (GPCRs) that mediate the physiological functions of adenosine. In the central nervous system adenosine $A_{2 A}$ receptors $\left(\mathrm{A}_{2 \mathrm{~A}} \mathrm{Rs}\right)$ are highly enriched in striatopallidal neurons where they form functional oligomeric complexes with other GPCRs such us the dopamine $\mathrm{D}_{2}$ receptor $\left(D_{2} R\right)$. Furthermore, it is assumed that the formation of balanced $A_{2 A} R / D_{2} R$ receptor oligomers are essential for correct striatal function as the allosteric receptor-receptor interactions established within the oligomer are needed for properly sensing adenosine and dopamine. Interestingly, $A_{2 A} R$ activation reduces the affinity of striatal $D_{2} R$ for dopamine and the blockade of $A_{2 A} R$ with specific antagonists facilitates function of the $\mathrm{D}_{2} \mathrm{R}$. Thus, it may be postulated that $\mathrm{A}_{2 \mathrm{~A}} \mathrm{R}$ antagonists are pro-dopaminergic agents. Therefore, $A_{2 A} R$ antagonists will potentially reduce the effects associated with dopamine depletion in Parkinson's disease (PD). Accordingly, this class of compounds have recently attracted considerable attention as potential therapeutic agents for PD pharmacotherapy as they have shown potential effectiveness in counteracting motor dysfunctions and also displayed neuroprotective and anti-inflammatory effects in animal models of PD. Overall, we provide here an update of the current state of the art of these $\mathrm{A}_{2 \mathrm{~A}} \mathrm{R}$-based approaches that are under clinical study as agents devoted to alleviate PD symptoms.
\end{abstract}




\section{INTRODUCTION}

Adenosine is a nucleoside which is mainly regarded as a retaliatory metabolite [1], thus it increases oxygen supply and decreases oxygen consumption. Consequently, adenosine potentially regulates a large amount of physiological processes (i.e. respiratory regulation, hormone action, neural function, platelet aggregation, lymphocyte differentiation and vascular tone). In addition, adenosine exerts a negative chronotropic and dromotropic effect on the heart, as well as it mediates inhibition of neurotransmitter release and lipolysis. In the central nervous system (CNS), adenosine acts principally as a negative neuromodulator for example decreasing striatal dopamine and glutamate release. In the brain, adenosine is produced by metabolism of adenosine triphosphate (ATP) when it is co-released with glutamate from nerve terminals and astrocytes [2]. Also, extracellular adenosine is related to the intracellular concentration of adenosine and nucleotides, such as ATP, adenosine monophosphate (AMP) and cyclic adenosine monophosphate (cAMP) [3]. In fact, in some brain areas, like the hippocampus, most of the extracellular adenosine seems to depend mainly on intracellular adenosine, the concentration of which is related to the rate of breakdown and synthesis of ATP [3]. Thus, adenosine would be released as a neuromodulator [4] by the effector cells in response to an increased metabolic demand [5]. Interestingly, in the striatum, it has been suggested that the main source of extracellular adenosine is intracellular cAMP [6]. Thus, since cAMP can only be generated by the action of the enzyme adenylyl cyclase, striatal extracellular adenosine would mostly reflect an increased activation of metabotropic receptors positively coupled to cAMP as a second messenger, for example the dopamine $D_{1}$ receptor. In addition, the dynamics of adenosine release in the cerebellum has been 
recently characterized by means of adenosine biosensors. Interestingly, by using this experimental approach it has been possible to demonstrate that adenosine release shares many characteristics of conventional neurotransmitter liberation such as a dependence on action potential width and homosynaptic plasticity [7].

Adenosine mediates its actions through activation of specific $\mathrm{G}$ protein-coupled receptors (GPCRs). Four subtypes of adenosine receptors (ARs) have been identified so far, namely $A_{1} R, A_{2 A} R, A_{2 B} R$ and $A_{3} R$, all of them bearing a distinctive pharmacological profile, tissue distribution and effector coupling [6]. Thus, while $A_{1} R$ are coupled to $G_{i / o}$, $A_{2 A} R$ are coupled to $G_{s / o l f}$ receptors. Interestingly, in the CNS the effects of adenosine are mainly mediated by $A_{1} R s$ and $A_{2 A} R s$ [8]. Hence, while $A_{1} R s$ are more widespread in the brain the $\mathrm{A}_{2 \mathrm{~A}} \mathrm{Rs}$ are highly concentrated in the striatum where they show both presynaptic and postsynaptic localization in $\gamma$-aminobutyric acid (GABA)-containing neurons (GABAergic neurons) [9]. Interestingly, presynaptic $A_{2 A} R$ form heteromers with the $A_{1} R$ in the glutamatergic terminals and it is believed that these heteromers act as concentration-dependent processors that exert subtle modulation of glutamate release [10]. Conversely, the postsynaptic $\mathrm{A}_{2 \mathrm{~A}} \mathrm{R}$ simultaneously heteromerize with the dopamine $D_{2}$ receptor $\left(D_{2} R\right)$ and the metabotropic glutamate type $5\left(\mathrm{mGlu}_{5}\right)$ receptor forming higher-order oligomers or receptor mosaics (or RMs) in the dendritic spine of enkephalinergic GABAergic medium spiny neurons (MSN) [11]. Interestingly, the $\mathrm{A}_{2 \mathrm{~A}} \mathrm{R} / \mathrm{D}_{2} \mathrm{R} / \mathrm{mGlu}_{5}$ receptor oligomeric complex, which is located extrasynaptically and adjacent to the glutamatergic synapse of the dendritic spine of MSNs, is activated by volume transmission and the receptor cross-talk within the complex helps to modulate postsynaptic plastic changes at the glutamatergic synapse [10]. Overall, GPCR 
oligomerization brings new and exciting possibilities to the therapy of $\mathrm{PD}$, since combined therapies acting at a named oligomer can have very different pharmacological effects from the ones expected through the monomers. Thus, the desired effect, e.g. the antiparkinsonian effect, can be mediated by the integrated activation of multiple effector systems but also by the allosterism or cross-talk mechanisms provided by the activation of the receptor monomers within the oligomer. Consequently, the existence of adenosine receptors containing oligomers in the striatum allows a much more elaborate tuning of the regulation of both presynaptic and postsynaptic neuronal responses in local striatal circuitry (Fig. 1A).

\section{Neurobiology of Parkinson's disease}

Parkinson's disease (PD) is a progressive systemic neurodegenerative disorder associated with, but not only, the loss of dopaminergic nigrostriatal neurons and is recognized as one of the most common neurological disorders, affecting approximately $1 \%$ of individuals over the age of 60 . While the initial symptoms within the pre-motor phase may be nonspecific (i.e. fatigue, depression, constipation, decreased sense of smell and sleep problem) the associated features and clinical signs at the motor phase include resting tremor, rigidity, bradykinesia, and postural instability. Unfortunately, as a neurodegenerative disease, the motor phase of this pathology continues to progress late in the disease to affect other brain areas (i.e. cortex), thus patients may then exhibit cognitive dysfunction and dementia [12].

The major neuropathologic findings underlying the clinical symptoms of PD is the loss of pigmented dopaminergic neurons located in the pars compacta of the substantia nigra 
(SNpc) [13]. However, some studies indicate that the loss of dopaminergic neurons occurs after there is significant loss and pathology of other brain regions including the locus coeruleus (LC), nucleus basalis of Meynert, dorsal raphe nucleus and the dorsal motor nucleus of the vagus $[14,15]$, and there is no explanation for this neuronal selection. In addition, a further neuropathological hallmark of PD is the existence of cytoplasmic proteinaceous inclusion bodies, called Lewy bodies, and dystrophic neurites, designated Lewy neurites [13], a feature common to other types of Parkinsonism. Interestingly, both Lewy bodies and Lewy neurites enclose a mixture of proteins, but $\alpha$ synuclein seems to be the main structural component [16]. Unfortunately, $60-80 \%$ of dopaminergic neurons are lost before the motor signs of PD emerge (pre-clinical phase). This fact points out the relevance of finding a biomarker of the pathology, especially for early stages of the disease.

The basal ganglia, which includes the $\mathrm{SN}$, modulates the cortical output necessary for normal movement. Inhibitory output to the thalamocortical motor circuit is directed from the globus pallidus pars interna (GPi) and the substantia nigra pars reticulata ( $\mathrm{SNr}$ ) in the basal ganglia where it acts to suppress movement. Accordingly, within the basal ganglia two major pathways exist and are referred to as the direct and indirect pathways (Fig. 1A), with a third hyperdirect excitatory corticosubthalamic pathway. Dopamine released by neurons of the substantia nigra pars compacta $(\mathrm{SNc})$ acts on the striatum via activation of either dopamine $\mathrm{D}_{1} \mathrm{R}$ or $\mathrm{D}_{2} \mathrm{R}$ subtypes. These receptors are distributed across two main populations of GABAergic MSNs, one that contains the neuropeptides dynorphin (DYN) and substance P (SP) and the other containing enkephalin (ENK) $[17,18]$. It is generally accepted that striatal DYN/SP-expressing neurons, also containing $\mathrm{D}_{1} \mathrm{R}$, constitute the 
direct pathway and project to the GPi/SNr (Fig. 1A). On the other hand, striatal ENKexpressing neurons containing $\mathrm{D}_{2} \mathrm{R}$ are part of the indirect pathway (Fig. 1A). However, a distinct population of MSNs with a unique phenotype, namely that co-expressing both DYN and ENK and also the $D_{1} R$ and the $D_{2} R$, have been recently described [19]. The role of these $D_{1} R / D_{2} R$-DYN/ENK neurons, which are highly expressed in the nucleus accumbens (NAc) core and shell but with very low expression in the caudate-putamen $(\mathrm{CPu})$, remains to be elucidated.

In normal non-pathological conditions, dopamine released by the SNc activates the direct pathway and inhibits the indirect pathway resulting in net inhibition of the GPi/SNr, thus resulting in a greater activity of the thalamocortical system that facilitates movements, and cognitive and behavioural outputs. However, in PD, because the loss of dopaminergic neurons in the $\mathrm{SNc}$, striatal dopamine is reduced and inhibition of the $\mathrm{GPi} / \mathrm{SNr}$ decreases. Thus, disinhibition of the $\mathrm{GPi} / \mathrm{SNr}$ leads to increased inhibitory output to the thalamus which suppresses movement (Fig. 1B). As a result, the central role that the striatum plays in processes such as motor activity control, motor learning and some forms of associative and visual learning [20] is altered. Overall, dopaminergic neurons from the SNc control the direct and indirect pathways within the basal ganglia via activation of dopamine $D_{1} R$ or $D_{2} R$. And, as described above, an interaction of dopamine receptors with glutamate and adenosine receptors in the same striatal neurons has been demonstrated, thus drugs acting on the latter group of receptors have been postulated as therapeutic tools in PD as they can modulate dopaminergic neurotransmission [21]. Furthermore, these receptor-receptor interactions highlight the potential role of the oligomers formed by these GPCRs as new therapeutic targets, since a 
multimodal drug-approach would lead restore normal function in pathological states such as PD [21].

\section{The treatment of PD: the rationale for using adenosine $A_{2 A} R$ antagonists}

The treatment of PD comprises mainly pharmacotherapy, although surgical interventions (i.e. deep brain stimulation) are also in use. However, all surgical procedures have associated risks and surgery is not suitable for everyone, typically only for advanced PD refractory to pharmacotherapy. Research around gene therapy and stem cell therapy is also promising but remains much underdeveloped thus far. So, at the moment the applications of these new therapies are still unknown. Therefore, the best management for most people with PD remains to be pharmacological treatments.

The vast majority of PD pharmacological treatments seek to restore dopamine signalling and thus to diminish the intensity of the motor and non-motor symptoms. Since the sixties the most effective therapy for the management of this disease is based on the use of drugs that mimic dopamine, initially the precursor L-DOPA (L-3,4-dihydroxyphenylalanine) [22] and later on other dopaminergic agents, which act to compensate for the loss of this neurotransmitter. For instance, other dopaminergic approaches include inhibition of dopamine turnover using monoamine oxidase type B (MAO-B) inhibitors (i.e. selegiline and rasagiline) [23], catechol $O$-methyl-transferase (COMT) inhibitors (i.e. entacapone and tolcapone) $[24,25]$ and dopamine receptor agonists (i.e. ergot $\mathrm{D}_{2} \mathrm{R}$ agonists: bromocriptine, pergolide, cabergoline; and non-ergot $\mathrm{D}_{2} \mathrm{R}$ agonists: pramipexole, ropinirole, rotigitine) (for review see [26]). Interestingly, although L-DOPA has been proved very efficacious in the treatment of PD symptoms, long term treatment can result 
in a loss of efficacy as motor functions deteriorate and the disease progresses. In addition, the appearance of motor complications such as dyskinesia and non-motor complications including psychosis and impulse-control disorders become more severe and problematic with continued treatment [27]. Thus, as PD progresses, fewer dopamine neurons are available to store and release L-DOPA-derived dopamine, and the patient's clinical status begins to fluctuate more and more closely in accordance with plasma L-DOPA levels. Exposing striatal dopamine receptors to fluctuating dopamine concentrations may cause a hypersensitivity that is expressed clinically as peak-dose dyskinesia. Finally, fluctuating L-DOPA-derived dopamine concentrations in association with the advancement of the disease may be responsible for the development of motor fluctuations and dyskinesia.

As mentioned above, the dopamine-based agents used in PD therapy have significant limitations, a fact that has forced the researchers to explore new non-dopaminergic PD treatments that circumvent these problems. Consequently, research is nowadays focused on finding better pharmacological therapies that provide efficacious relief of parkinsonian symptoms while evoking less risk of dyskinesia and associated motor-complications. Interestingly, another important area of research associated to these non-dopaminergicbased PD drugs is related to the neuroprotection of the dopaminergic neurons and other neuronal types (i.e. brain stem and LC neurons), in order to slow down the progression of the disease, but unfortunately still no neuroprotective therapy exists. Accordingly, we will delineate here some in vivo studies revolving around neuroprotection (i.e. protection of surviving neurons) and we will leave aside those related to neurorestoration (i.e. return to functioning phenotype of quiescent neurons) as the latter issue may constitute a review into itself $[28,29]$. 
As introduced above, a promising treatment for the disease is based on the modulation of dopaminergic neurotransmission by means of an indirect action towards dopamine receptors. These non-dopaminergic-based PD therapies may offer advantages over dopamine medications, possibly including fewer side effects. Interestingly, one nondopaminergic approach that has received considerable attention by the scientific community is the modulation exerted by adenosine receptors in general and by the $\mathrm{A}_{2 \mathrm{~A}} \mathrm{R}$ in particular on the dopaminergic neurotransmission. Adenosine, as a neuromodulator, synchronizes responses to several neurotransmitters including dopamine in brain areas that are important for motor function, mood, and learning and memory [3]. Interestingly, it has been recently described that the $\mathrm{D}_{2} \mathrm{R}$ interacts with the $\mathrm{A}_{2 \mathrm{~A}} \mathrm{R}$ and the $\mathrm{mGlu}_{5}$ receptor in striatopallidal GABAergic neurons [11], in such a manner that $A_{2 A} R$ and mGlu $u_{5}$ receptor agonists act synergistically to reduce the affinity of $D_{2} R$ agonist binding sites [30]. In addition, by using the novel resonance energy transfer technique SRET [31] and through bimolecular fluorescence complementation techniques the existence of $\mathrm{D}_{2} \mathrm{R} / \mathrm{A}_{2 \mathrm{~A}} \mathrm{R} / \mathrm{mGlu}_{5}$ receptor oligomer in living cells has recently been demonstrated [11]. Moreover, coimmunoprecipiation studies in rat striatal tissue have confirmed this interaction [11]. Interestingly, in striatopallidal GABAergic neurons, it has been demonstrated that $\mathrm{D}_{2} \mathrm{R} / \mathrm{A}_{2 \mathrm{~A}} \mathrm{R}$ dimerization results in a reciprocal inhibition and in a final negative outcome in the cAMP- and phospholipase C-mediated signalling [32]. Thus, $A_{2 A} R$ blockade facilitates $D_{2} R$ signalling and thereby might in theory restore $D_{2} R$ mediated striatal neurotransmission. Overall, the presence of the $\mathrm{D}_{2} \mathrm{R} / \mathrm{A}_{2 \mathrm{~A}} \mathrm{R} / \mathrm{mGlu}_{5}$ receptor oligomeric complex and the cross-talk within the receptor heteromer might help 
to modulate postsynaptic plasticity at the glutamatergic synapse, and thus the output of striatopallidal GABAergic neurons (Fig. 1).

Increased knowledge about oligomerization has helped scientist to the design and development of specific $\mathrm{A}_{2 \mathrm{~A}} \mathrm{R}$ antagonists for the treatment of PD [33]. Interestingly, the obtained preclinical data suggest that these $A_{2 A} R$ antagonist (i.e. istradefylline) might have major applications in the treatment of $\mathrm{PD}$ : a) providing motor benefit as monotherapy; b) potentiating the benefit of dopamine agonists and allowing a lowering of L-DOPA dose; c) preventing the development of L-DOPA induced dyskinesias (LID), and; d) allowing the maintenance of the motor response with less dyskinesia using a lower L-DOPA dose [34]. Indeed, $\mathrm{A}_{2 \mathrm{~A}} \mathrm{R}$ antagonists have been shown to possess antiparkinsonian properties in human PD patients with LID [35]. This antiparkinsonian effect is probably due to the action of the $A_{2 A} R$ antagonist at $A_{2 A} R / D_{2} R$ oligomers, thereby reducing the $A_{2 A} R$-mediated inhibition of $D_{2} R$ signalling. Furthermore, the status of some oligomers might be altered in pathological situations such as PD or LID. In line with this, the appearance of LID has been suggested to be due to the dominance of $A_{2 A} R / A_{2 A} R$ homodimers versus $A_{2 A} R / D_{2} R$ heterodimers and $D_{2} R / D_{2} R$ homodimers, thus with an uncontrolled increment in the $\mathrm{A}_{2 \mathrm{~A}} \mathrm{R}$ signalling [36]. Indeed, the expression of $\mathrm{A}_{2 \mathrm{~A}} \mathrm{R}$ has been shown to be increased in the brain of PD patients with dyskinesias and it has been postulated that the increased synthesis of $\mathrm{A}_{2 \mathrm{~A}} \mathrm{Rs}$ in striatopallidal pathway neurons is associated with the development of dyskinesias following long-term L-DOPA therapy in PD [37]. Interestingly, this hints at another potential therapeutical use of $A_{2 A} R$ antagonists in $\mathrm{PD}$, namely their use not only as anti-parkinsonian agents in patients with pre-existing LID but also its use de novo in combination with dopaminergic agents to 
prevent the development of dyskinesias [38].[39] Recently, the availability of $\mathrm{A}_{2 \mathrm{~A}} \mathrm{Rs}$ in PD patients with and without LIDs was investigated by using positron emission tomography (PET) scan and the $\left[{ }^{11} \mathrm{C}\right] \mathrm{SCH} 442416$ compound [40]. Interestingly, while the thalamic $\mathrm{A}_{2 \mathrm{~A}} \mathrm{R}$ availability was similar in PD subjects with and without LIDs (and similar to the control subjects) the $\mathrm{A}_{2 \mathrm{~A}} \mathrm{R}$ binding in the $\mathrm{CPu}$ of $\mathrm{PD}$ subjects with LIDs was significantly increased when compared to the PD subjects without LIDs [40]. Overall, as patients with PD with LIDs show increased $A_{2 A} R$ expression in the striatum, and thus altered adenosinergic transmission in this brain region, it sounds reasonable to start thinking in clinical trials using $\mathrm{A}_{2 \mathrm{~A}} \mathrm{R}$ antagonists for the treatment of these motor complications.

As mentioned earlier, another important issue around the research related to PD concerns the direct neuroprotection of the dopaminergic neurons in order to slow down the progression of the disease. Interestingly, $\mathrm{A}_{2 \mathrm{~A}} \mathrm{R}$ antagonism or gene $\mathrm{KO}$ has been found to be neuroprotective in different models of neurodegeneration, such as Alzheimer's disease, Huntington's disease, and cerebral ischemia [41-44]. Indeed, in preclinical studies using an animal model of PD (i.e. the subchronic MPTP mouse model) it was shown that the concomitant treatment with SCH58261, an $\mathrm{A}_{2 \mathrm{~A}} \mathrm{R}$ antagonist, attenuated dopamine cell loss and gliosis in the SNc and in the striatum [45]. In brief, the SCH58261 injected half an hour before MPTP administration, and keep after MPTP treatment discontinuation, prevented the degeneration of nigrostriatal $\mathrm{TH}$ positive neurons [45]. Also, the selective deletion of neuron-specific forebrain $A_{2 A} R$ prevented MPTP-induced dopamine neuron degeneration and glial activation [45]. Recently, another $\mathrm{A}_{2 \mathrm{~A}} \mathrm{R}$ antagonist, the ST1535, showed a neuroprotective and anti-inflammatory effect in the 
same animal model [39]. Collectively, these results provide evidence of the key role played by the blockade of $\mathrm{A}_{2 \mathrm{~A}} \mathrm{R}$ in $\mathrm{PD}$ neuroprotection. Overall, with the described neuroprotective effect on dopaminergic neuron toxicity the $A_{2 A} R$ antagonists have opened new prospects as symptomatic antiparkinsonian drugs, and thus justifyied the implementation of clinical trials studying the benefit of using these kinds of drugs early in the treatment of PD.

\section{Clinical evaluation of adenosine $A_{2 A} R$ antagonists in PD}

From the wide-range of non-dopaminergic drugs targeted at the management of PD (for review see [46]), we will focus here particularly on the clinical efficacy and the described outcomes of the $\mathrm{A}_{2 \mathrm{~A}} \mathrm{R}$-based approaches that are in at least phase II clinical development for the treatment of PD. Interestingly, several preclinical studies point to the benefits of adenosine $\mathrm{A}_{2 \mathrm{~A}} \mathrm{R}$ antagonists on the symptomatic management of $\mathrm{PD}$ [47-50]. Accordingly, selective adenosine $\mathrm{A}_{2 \mathrm{~A}} \mathrm{R}$ antagonists, such as istradefylline (KW-6002), preladenant (SCH-420814), vipadenant (BIIB014), SYN115 and ST-1535, are being assessed in clinical studies as potential antiparkinsonian drugs [46, 51, 52]. Thus, we will describe here, as a prototypical $\mathrm{A}_{2 \mathrm{~A}} \mathrm{R}$-based antiparkinsonian agent, the development of the selective adenosine $A_{2 A} R$ antagonist istradefylline, which is the first selective adenosine $A_{2 A} R$ antagonist well studied in preclinical studies and clinical trials.

Istradefylline was originally assessed as monotherapy and adjunctive therapy in rodent and primate models of $\mathrm{PD}$, thus the obtained preclinical data suggested that this $\mathrm{A}_{2 \mathrm{~A}} \mathrm{R}$ antagonist may have major applications in the management of $\mathrm{PD}$ [53-58]. Accordingly, it was initially proposed that istradefylline might provide motor benefits as monotherapy 
and also it was postulated that it may potentiate the benefit of dopamine agonists. Hence, the combined use of istradefylline with L-DOPA would allow lowering L-DOPA doses used in PD therapy and thus it would be prevented, in theory, the development of LID (i.e. maintenance of the motor response with less dyskinesia using a lower L-DOPA dose) [34]. Therefore, with these encouraging preclinical data, clinical effects of istradefylline were studied in human beings [59].

Firstly, regarding data from population pharmacokinetic analysis of istradefylline in healthy volunteers and patients with PD it was shown the drug fits to a two-compartment model with first order absorption. Thus, in clinical pharmacokinetics studies, the terminal elimination half life of istradefylline was of 70 to 118 hours, with a peak time of 2 to 5 hours. Istradefylline inhibits and is primarily metabolized by cytochrome P450 3A4 (CYP3A4) and is also an inhibitor of the efflux transporter P-glycoporotein. Smoking and CYP3A4 inhibitors as concomitant drugs alter istradefylline clearance and systemic exposure. As a result, istradefylline area under the concentration-time curve at steadystate increased $35 \%$ in the presence of CYP3A4 inhibitors and decreased 38\% in smokers [60].

The clinical effects of istradefylline were evaluated in multicentre double-blind, placebocontrolled randomised clinical trials involving patients with moderate or advanced PD $[35,61-65][63]$, while only in one clinical trial the effects of treatment were examined in patients with early PD [66] (Table 1). To briefly summarize, the length of the studies was short (12 weeks) (Table 1). The mean age of patients included in clinical trials ranged from 63 to 65 years old and approximately $60 \%$ were men, while the mean time since diagnosis of disease was from 8 to 10 years (Table 2). The clinical trials evaluated a wide 
range of istradefylline doses (from 5 to $80 \mathrm{mg}$ ), but the most studied doses were 20 and $40 \mathrm{mg}$ (Table 1). On the other hand, patients were usually treated with L-DOPA (mean daily dosage from $400 \mathrm{mg}$ to $857 \mathrm{mg}$ ) (Table 2), and often also with other concomitant antiparkinsonian medications (Table 2), while only in one clinical trial patients were treated neither with L-DOPA nor with other dopaminergic drugs (Table 1). The mean time since onset of motor complications of patients was 3 years and the mean time spent by patients in the "off" state was 6 hours (Table 2). Finally, drugs were generally well tolerated in all the clinical trials mentioned above. Thus, on average, $88 \%$ of subjects in each group (i.e. istradefylline and placebo) completed double-blind treatment when all istradefylline clinical trials were analyzed (853 out of 968 istradefylline treated patients and 435 out of 491 placebo treated patients), while about only $11-12 \%$ of drug-treated patients discontinued prematurely the treatment (115 out of 968 istradefylline treated patients and 56 out of 491 placebo treated patients). The most common reasons $(\sim 50 \%)$ for discontinuing treatment were the adverse events (61 out of 115 istradefylline discontinued patients and 27 out of 56 placebo discontinued patients), followed by withdraw consent $(16.5 \%$ in istradefylline discontinued patients and $25 \%$ in placebo discontinued patients), lack of efficacy $(7.7 \%$ in istradefylline discontinued patients and $19.6 \%$ in placebo discontinued patients), non-compliance or protocol violation ( $13 \%$ in istradefylline discontinued patients and $7 \%$ in placebo discontinued patients) and other reasons $(8.7 \%$ in istradefylline discontinued patients and $1.8 \%$ in placebo discontinued patients).

The clinical trials evaluating istradefylline efficacy targeted symptoms associated with dopamine replacement and therapy of dyskinesia. The most evaluated primary variable 
for assessing clinical efficacy in clinical trials was the change in time spent on "off" state from baseline to end point. The typical primary endpoint was the change from baseline at end point in the clinical rating scale of disease Unified Parkinson's Disease Rating Scale (UPDRS) part III subscale [66] (Table 1). Needless to say, available data on the outcomes are difficult to interpret. However, in clinical trials, istradefylline reduced the time spent in the "off" state in L-DOPA-treated PD patients with motor complications but the magnitude of the drug effect was small and with doubtful clinical significance (Table 3). In addition, most studies did not reported significant benefit of istradefylline on parkinsonian symptoms as measured by the UPDRS, with the exception of a Japanase clinical trial (Table 3). In the Mizuno et al study, the UPDRS part III subscale score on state was reduced by 5.7 at endpoint in both istradefylline groups (20 and $40 \mathrm{mg}$ ) and 3.7 in the placebo group (Table 3) [65]. Thus, the differences between the two istradefylline groups and placebo were statistically significant, but again the relatively modest improvement with istradefylline (only 2 points on a scale with a total of 68 points) raised the question of clinical relevance. On the other hand, istradefylline as monotherapy in patients with early PD was not effective in improving motor symptoms [66] (Table 3). With regard to treatment-related adverse events, they were reported in between $59 \%$ and $89 \%$ (average of $68.4 \%$ ) of subjects receiving istradefylline and between $56 \%$ and $86 \%$ (average of $67.6 \%$ ) of subjects receiving placebo. Globally, the frequency of adverse events was not different between groups of patients treated with doses of $20 \mathrm{mg}$ and those treated with doses of $40 \mathrm{mg}$. On the other hand, adverse events caused discontinuation of the treatment in $6 \%$ of the patients, and were severe in almost $4 \%$ of patients treated with istradefylline and $2 \%$ of the placebo-treated. Finally, the most frequently reported 
treatment-related adverse events in patients receiving istradefylline were nervous system, gastrointestinal-, psychiatric- and respiratory disorders. In particular, dyskinesia, dizziness, nausea, constipation and hallucinations were the most frequently reported events (Table 4). Overall, a lot of effort has been put in the study of this first adenosine $\mathrm{A}_{2 \mathrm{~A}} \mathrm{R}$-based drug designed for the treatment of PD and yet the results are modest.

Interestingly, a new set of $\mathrm{A}_{2 \mathrm{~A}} \mathrm{R}$-based antiparkinsonian agents are under study. For instance, a phase II, double-blind, placebo-controlled randomised trial that assessed efficacy and safety of preladenant in 253 patients with PD and motor fluctuations who were receiving L-DOPA and other antiparkinsonian drugs, found significant although slight changes in mean daily "off" time when comparing the effects of the selective adenosine $A_{2 A} R$ antagonist with placebo [67]. On the other hand, the most common adverse events in the combined preladenant group versus placebo were similar -i.e. somnolence (10\% vs. $6 \%$ ), dyskinesia ( $9 \%$ vs. 13\%), nausea ( $9 \%$ vs. $11 \%)$, constipation ( $8 \%$ vs. $2 \%$ ), and insomnia ( $8 \%$ vs. $9 \%$ ). Again, although initial results show that these drugs are safe and well tolerated, its efficacy in PD patients has yet to be shown conclusive.

\section{FUTURE CHALLENGES}

$\mathrm{A}_{2 \mathrm{~A}} \mathrm{R}$ antagonists remain one of the most attractive potential non-dopaminergic classes of drugs for the management of PD as they have shown effectiveness in counteracting parkinsonian motor symptoms and have also displayed potential neuroprotective and antiinflammatory effects in animal models of PD. However, the translation of these promising pre-clinical observations into benefit in PD patients has yet to be conclusively 
demonstrated. Thus, the continued optimisation of new symptomatic $\mathrm{A}_{2 \mathrm{~A}} \mathrm{R}$-based treatments for many of the motor and non-motor problems of PD is required. Interestingly, a new generation of $\mathrm{A}_{2 \mathrm{~A}} \mathrm{R}$ antagonists is now under development. Accordingly, there are several phase II and III ongoing clinical trials evaluating the efficacy and safety of new selective $\mathrm{A}_{2 \mathrm{~A}} \mathrm{R}$ antagonist drugs in patients with PD (Table 8). Finally, it is important to mention that key to success in this endeavour is the improvement of translation of preclinical findings into phase II and III endpoints through better clinical study designs employing appropriate study populations. Overall, the need for alternative pharmacotherapies in $\mathrm{PD}$ is progressively clearer and non-dopaminergic drugs such as $\mathrm{A}_{2 \mathrm{~A}} \mathrm{R}$ antagonists constitute a realistic opportunity to reach this end.

\section{ACKNOWLEDGMENTS}

This work was supported by grants SAF2008-01462 and Consolider-Ingenio CSD200800005 from Ministerio de Ciencia e Innovación and the ICREA Academia-2010 award from the Catalan Institution for Research and Advanced Studies to FC. The authors belong to the "Neuropharmacology and Pain" accredited research group (Generalitat de Catalunya, 2009 SGR 232).

\section{ABBREVIATIONS}

$\begin{array}{lll}\mathrm{A}_{1} \mathrm{R} & = & \text { adenosine } \mathrm{A}_{1} \text { receptor } \\ \mathrm{A}_{2 \mathrm{~A}} \mathrm{R} & = & \text { adenosine } \mathrm{A}_{2 \mathrm{~A}} \text { receptor } \\ \mathrm{ATP} & = & \text { adenosine triphosphate } \\ \mathrm{cAMP} & = & \text { cyclic adenosine monophosphate }\end{array}$




\begin{tabular}{|c|c|c|}
\hline CNS & $=$ & central nervous system \\
\hline $\mathrm{CPu}$ & $=$ & caudate-putamen \\
\hline CYP3A4 & $=$ & cytochrome P450 3A4 \\
\hline $\mathrm{D}_{1} \mathrm{R}$ & $=$ & dopamine $\mathrm{D}_{1}$ receptor \\
\hline $\mathrm{D}_{2} \mathrm{R}$ & $=$ & dopamine $\mathrm{D}_{2}$ receptor \\
\hline DYN & $=$ & dynorphin \\
\hline ENK & $=$ & enkephalin \\
\hline GABA & $=$ & $\gamma$-aminobutyric acid \\
\hline GPCR & $=$ & G protein-coupled receptor \\
\hline GPi & $=$ & globus pallidus pars interna \\
\hline $\mathrm{LC}$ & $=$ & locus coeruleus \\
\hline L-DOPA & $=$ & L-3,4-dihydroxyphenylalanine \\
\hline LID & $=$ & L-DOPA induced dyskinesias \\
\hline $\mathrm{mGlu}_{5}$ & $=$ & metabotropic glutamate type 5 receptor \\
\hline МPTP & $=$ & 1-methyl-4-phenyl-1,2,3,6-tetrahydropyridine \\
\hline MSN & $=$ & GABAergic medium spiny neurons \\
\hline NAc & $=$ & nucleus accumbens \\
\hline PD & $=$ & Parkinson's disease \\
\hline $\mathrm{SN}$ & $=$ & substantia nigra \\
\hline $\mathrm{SNc}$ & $=$ & substantia nigra pars compacta \\
\hline $\mathrm{SNr}$ & $=$ & substantia nigra pars reticulata \\
\hline SP & $=$ & substance $\mathrm{P}$ \\
\hline UPDRS & $=$ & Unified Parkinson's Disease Rating Scale \\
\hline
\end{tabular}




\section{FIGURE LEGENDS}

\section{Fig. 1. Scheme of the basal ganglia circuitry and its connection to the} thalamocortical circuit in both normal (A) and PD (B) conditions. Dopaminergic neurons from the substantia nigra pars compacta $(\mathrm{SNc})$ control the direct and indirect pathways within the basal ganglia via activation of $D_{1} R$ or $D_{2} R$. Thus, the striatum is linked to substantia nigra pars reticulata and globus pallidus pars interna complex ( $\mathrm{SNr}-$ GPi) via direct (striatonigral) and indirect (striatal-pallidal-subthalamic-nigral) pathways. The co-localisation of receptors for dopamine, glutamate and adenosine in the same striatal neurons puts into relevance the potential role of oligomers formed by these GPCRs and postulated the use of striatal glutamate and adenosine receptors as therapeutic targets in PD. GPe: globus pallidus pars externa; STN: subthalamic nucleus; ENK: enkephalinergic neuron; DYN: dynorphinergic neuron. 
Table 1. Randomised clinical trials with istradefylline in Parkinson's disease (PD)

\begin{tabular}{|c|c|c|c|c|c|}
\hline $\begin{array}{c}\text { Authors (year) } \\
\text { Study } \\
\text { Country/ies }\end{array}$ & $\begin{array}{c}\text { Phase and } \\
\text { Design clinical } \\
\text { trial }\end{array}$ & Patients & $\begin{array}{l}\text { Treatment } \\
\text { (drugs, doses } \\
\text { and length) }\end{array}$ & $\begin{array}{l}\text { Primary } \\
\text { outcome }\end{array}$ & $\begin{array}{c}\text { Other } \\
\text { outcomes }\end{array}$ \\
\hline $\begin{array}{c}\text { Bara-Jimenez et } \\
\text { al } \\
(2003) \\
\text { USA } \\
{[61]}\end{array}$ & $\begin{array}{l}\text {-Proof-of } \\
\text { principle } \\
\text {-Double-blind, } \\
\text { placebo- } \\
\text { controlled } \\
\text { randomised trial } \\
\text { (randomisation } \\
\text { ratio 3:1) }\end{array}$ & $\begin{array}{l}15 \text { subjects with } \\
\text { moderate to } \\
\text { advanced PD }\end{array}$ & $\begin{array}{l}\bullet \text { Istradefylline } \\
40 \text { mg/day oral } \\
\text { vs. placebo } \\
\text {-Istradefylline } \\
80 \text { mg/day oral } \\
\text { vs. placebo } \\
\rightarrow 6 \text { weeks }\end{array}$ & $\begin{array}{l}\bullet \text { Exploratory } \\
\text { study } \\
\bullet \text { No primary } \\
\text { efficacy variable } \\
\text { was defined. }\end{array}$ & $\begin{array}{l}\text {-UPDRS III } \\
\text { motor scale } \\
\text { scores } \\
\text {-Dyskinesia } \\
\text { scales } \\
\text {-Duration of } \\
\text { LD action } \\
\text { - Adverse events }\end{array}$ \\
\hline $\begin{array}{c}\text { Hauser et al } \\
(2003) \\
\text { US-001 Study } \\
\text { USA } \\
{[62]}\end{array}$ & $\begin{array}{l}\bullet \text { Phase II } \\
\bullet \text { Multicentric } \\
\text { double-blind, } \\
\text { placebo- } \\
\text { controlled } \\
\text { randomised } \\
\text { trial } \\
\text { (randomisation } \\
\text { ratio } 1: 1: 1 \text { ) }\end{array}$ & $\begin{array}{l}83 \mathrm{LD} \text { treated } \\
\text { patients with } \\
\text { motor } \\
\text { fluctuations and } \\
\text { dyskinesias }\end{array}$ & $\begin{array}{l}\bullet \text { Istradefylline } \\
5 / 10 / 20 \mathrm{mg} / \text { day } \\
\text { oral } \\
\text { vs. placebo } \\
\bullet \text { Istradefylline } \\
10 / 20 / 40 \\
\mathrm{mg} / \text { day oral } \\
\text { vs. placebo } \\
\rightarrow 12 \text { weeks }\end{array}$ & $\begin{array}{l}\text {-Exploratory } \\
\text { study. } \\
\text { •No primary } \\
\text { efficacy variable } \\
\text { was defined. }\end{array}$ & $\begin{array}{l}\text { - Off time } \\
\text { - On time with } \\
\text { dyskinesia } \\
\text {-UPDRS scores } \\
\text { - Dyskinesia } \\
\text { scales } \\
\text { - Adverse events }\end{array}$ \\
\hline $\begin{array}{c}\text { LeWitt et al } \\
\text { (2008) } \\
\text { 6002-US-005 } \\
\text { Study } \\
\text { USA, Canada } \\
\text { [35] }\end{array}$ & $\begin{array}{l}\bullet \text { Phase III } \\
\bullet \text { Multicentric } \\
\text { double-blind, } \\
\text { placebo- } \\
\text { controlled } \\
\text { randomised trial } \\
\text { (randomisation } \\
\text { ratio 2:1) }\end{array}$ & $\begin{array}{l}196 \text { LD subjects } \\
\text { with PD } \\
\text { experiencing } \\
\text { prominent } \\
\text { wearing-off } \\
\text { motor } \\
\text { fluctuations }\end{array}$ & $\begin{array}{l}\text {-Istradefylline } \\
40 \text { mg per day } \\
\text { oral vs. placebo } \\
\rightarrow 12 \text { weeks }\end{array}$ & $\begin{array}{l}\bullet \text { Percentage of } \\
\text { "off" time from } \\
\text { baseline to end } \\
\text { point }\end{array}$ & $\begin{array}{l}\text {-On time with } \\
\text { dyskinesia } \\
\text {-On time } \\
\text { without } \\
\text { dyskinesia } \\
\text {-UPDRS scores } \\
\text {-CGI-I scores } \\
\text { - Adverse events }\end{array}$ \\
\hline $\begin{array}{c}\text { Hauser et al } \\
\text { (2008) } \\
\text { 6002-US-013 } \\
\text { Study } \\
\text { USA } \\
\text { [63] }\end{array}$ & $\begin{array}{l}\bullet \text { Phase III } \\
\bullet \text { Multicentric } \\
\text { double-blind, } \\
\text { placebo- } \\
\text { controlled } \\
\text { randomised trial } \\
\text { (randomisation } \\
\text { ratio 1:1) }\end{array}$ & $\begin{array}{l}231 \text { subjects } \\
\text { with LD treated } \\
\text { PD who have } \\
\text { motor } \\
\text { fluctuations }\end{array}$ & $\begin{array}{l}- \text { Istradefylline } \\
20 \text { mg per day } \\
\text { oral vs. placebo } \\
\rightarrow 12 \text { weeks }\end{array}$ & $\begin{array}{l}\bullet \text { Percentage of } \\
\text { "off" time from } \\
\text { baseline to end } \\
\text { point. }\end{array}$ & $\begin{array}{l}\text { - On time with } \\
\text { dyskinesia } \\
\text { - On time } \\
\text { without } \\
\text { dyskinesia } \\
\text {-UPDRS scores } \\
\text { - CGI-S scores } \\
\text { - PGI-I scores } \\
\text { - Adverse events }\end{array}$ \\
\hline $\begin{array}{c}\text { Stacy et al. } \\
\text { (2008) } \\
\text { 6002-US-006 } \\
\text { Study } \\
\text { USA } \\
\text { [64] }\end{array}$ & $\begin{array}{l}\text {-Phase III } \\
\text { - Multicentric } \\
\text { double-blind, } \\
\text { placebo- } \\
\text { controlled, } \\
\text { randomised } \\
\text { trial } \\
\text { (randomisation } \\
\text { ratio } 1: 2: 2 \text { ) }\end{array}$ & $\begin{array}{l}395 \text { subjects } \\
\text { with LD treated } \\
\text { PD who have } \\
\text { motor } \\
\text { fluctuations }\end{array}$ & $\begin{array}{l}- \text { Istradefylline } \\
20 \text { mg per day } \\
\text { oral vs. placebo } \\
\text { - Istradefylline } \\
40 \text { mg per day } \\
\text { oral vs. placebo } \\
\rightarrow 12 \text { week }\end{array}$ & $\begin{array}{l}\bullet \text { Percentage of } \\
\text { "off" time from } \\
\text { baseline to end } \\
\text { point. }\end{array}$ & $\begin{array}{l}\text {-On time with } \\
\text { dyskinesia } \\
\text {-On time } \\
\text { without } \\
\text { dyskinesia } \\
\text {-UPDRS scores } \\
\text {-CGI-S scores } \\
\text {-Adverse events }\end{array}$ \\
\hline
\end{tabular}




\begin{tabular}{|c|c|c|c|c|c|}
\hline $\begin{array}{c}\text { Fernández et al } \\
(2010) \\
\text { 6002-US-051 } \\
\text { trial } \\
\text { USA } \\
\text { [66] }\end{array}$ & $\begin{array}{l}\text {-Phase II } \\
\bullet \text { Multicentric } \\
\text { double-blind, } \\
\text { placebo- } \\
\text { controlled } \\
\text { randomised trial } \\
\text { (randomisation } \\
\text { ratio 1:1) }\end{array}$ & $\begin{array}{l}197 \text { patients } \\
\text { without } \\
\text { treatment with } \\
\text { dopaminergic } \\
\text { agents or LD }\end{array}$ & $\begin{array}{l}\bullet \text { Istradefylline } \\
40 \text { mg per day } \\
\text { oral vs. placebo } \\
\rightarrow 12 \text { week }\end{array}$ & $\begin{array}{l}\text { Change from } \\
\text { baseline at } \\
\text { endpoint in the } \\
\text { UPDRS part III } \\
\text { subscale score }\end{array}$ & $\begin{array}{l}\text {-UPDRS } \\
\text { subscale I, II, } \\
\text { IVA scores } \\
\text {-UPDRS total } \\
\text { score } \\
\text {-WPI score } \\
\text { - PGI-I score } \\
\text {-CVLT score } \\
\text { - VFT score } \\
\text { - Adverse events }\end{array}$ \\
\hline $\begin{array}{c}\text { Mizuno et al } \\
(2010) \\
\text { The Japanase } \\
\text { Istradefylline } \\
\text { Sudy } \\
\text { Japan } \\
{[65]}\end{array}$ & $\begin{array}{l}\text {-Phase III } \\
\text { - Mulicentric } \\
\text { double-blind, } \\
\text { placebo- } \\
\text { controlled } \\
\text { randomised trial } \\
\text { (assigned by } \\
1: 1: 1 \\
\text { randomisation } \\
\text { ratio) }\end{array}$ & $\begin{array}{l}363 \text { patients } \\
\text { with LD treated } \\
\text { PD who have } \\
\text { motor } \\
\text { fluctuations }\end{array}$ & $\begin{array}{l}\text { - Istradefylline } \\
20 \text { mg per day } \\
\text { oral vs. placebo } \\
\text {-Istradefylline } \\
40 \text { mg per day } \\
\text { oral vs. placebo } \\
\rightarrow 12 \text { week }\end{array}$ & $\begin{array}{l}\text { - Change in } \\
\text { daily off time } \\
\text { from baseline at } \\
\text { endpoint }\end{array}$ & $\begin{array}{l}\text { - On time with } \\
\text { dyskinesia } \\
\text {-UPDRS part } \\
\text { III subscale } \\
\text { score } \\
\text { - CGI-I score } \\
\text { - Adverse events }\end{array}$ \\
\hline
\end{tabular}

UPDRS: Unified Parkinson's Disease Rating Scale; CGI-I: Clinical Global Impression-Improvement scale; CGIS: Clinical Global Impression-Severity of Illness scale; PGI-I: Patient Global Impression-Improvement scale; WPI: Webster Performance Index; CVLT: California Verbal Learning Test; VFT: Verbal FluencyTest. 
Table 2. Baseline demographic and disease characteristics of the patients.

\begin{tabular}{|c|c|c|c|c|c|c|c|}
\hline & $\begin{array}{c}\text { Bara-Jimenez } \\
2003\end{array}$ & $\begin{array}{l}\text { Hauser } \\
2003\end{array}$ & $\begin{array}{l}\text { LeWitt } \\
2008\end{array}$ & $\begin{array}{c}\text { Hauser } \\
2008\end{array}$ & $\begin{array}{l}\text { Stacy } \\
2008\end{array}$ & $\begin{array}{l}\text { Fernández } \\
2010\end{array}$ & $\begin{array}{c}\text { Mizuno } \\
2010\end{array}$ \\
\hline Age & 63 & 64 & 63 & 63 & $63-65$ & 63 & 65 \\
\hline Gender male\% & $53 \%$ & $57 \%$ & $60 \%$ & $66 \%$ & $64-68 \%$ & $60 \%$ & $43,5-44 \%$ \\
\hline \multicolumn{8}{|l|}{$\begin{array}{c}\text { Duration of } \\
\text { illness and symptoms }\end{array}$} \\
\hline $\begin{array}{l}\text { Mean time since } \\
\text { diagnosis of PD }\end{array}$ & 8.1 years & NR & 9.3 years & 10 years & 3 years & 1.4 years & 8 years \\
\hline $\begin{array}{l}\text { Mean time since onset } \\
\text { of motor complications }\end{array}$ & NR & NR & 3.3 years & 4 years & NR & NR & 3 years \\
\hline $\begin{array}{l}\text { Mean time spent } \\
\text { in the OFF state }\end{array}$ & NR & 6 hours & 6 hours & 6.7 hours & 5.7 hours & - & 6 hours \\
\hline $\begin{array}{l}\text { Mean time ON state } \\
\text { without dyskinesia }\end{array}$ & NR & NR & 7.3 hours & 7.3 hours & $7-8$ hours & - & NR \\
\hline $\begin{array}{c}\text { Mean time ON state } \\
\text { with dyskinesia, mean }\end{array}$ & NR & 5.1 hours & 2.9 hours & 2.8 hours & 3-4 hours & - & NR \\
\hline $\begin{array}{l}\text { Mean time ON state with } \\
\text { troublesome dyskinesia }\end{array}$ & NR & NR & 0.6 hours & 0.7 hours & 0.6-1 hours & - & NR \\
\hline $\begin{array}{c}\text { Mean time ON state } \\
\text { without troublesome } \\
\text { dyskinesia }\end{array}$ & NR & NR & 9.5 hours & 9.4 hours & 10 hours & - & NR \\
\hline \multicolumn{8}{|l|}{$\begin{array}{c}\text { Clinical Rating scales } \\
\text { of the disease }\end{array}$} \\
\hline $\begin{array}{l}\text { UPDRS Part II } \\
\text { subscale score }\end{array}$ & NR & NR & 6.4 & 6.8 & $6-7$ & 8.2 & NR \\
\hline $\begin{array}{l}\text { UPDRS Part III subscale } \\
\text { score (on-state), mean }\end{array}$ & NR & 18.2 & 17.7 & 23.9 & $17-18$ & 20.6 & 21 \\
\hline \multicolumn{8}{|l|}{ Concomitant medications } \\
\hline L-DOPA \% & $100 \%$ & $100 \%$ & $100 \%$ & $100 \%$ & $100 \%$ & 0 & $100 \%$ \\
\hline Daily dosage of L-DOPA & $857 \mathrm{mg}$ & $818 \mathrm{mg}$ & $560 \mathrm{mg}$ & $652 \mathrm{mg}$ & NR & - & $400 \mathrm{mg}$ \\
\hline Dopamine agonists & NR & $52 \%$ & $89,9 \%$ & $4 \%-42 \%$ & $91 \%$ & - & $92-96 \%$ \\
\hline Selegiline & NR & $22.2 \%$ & $18.6 \%$ & $11.3 \%$ & $15-16 \%$ & - & $50-54 \%$ \\
\hline Entacapone & NR & $29.6 \%$ & $41.1 \%$ & $47.8 \%$ & $41-44 \%$ & - & $13-19 \%$ \\
\hline Amantadine & NR & NR & $27.1 \%$ & $32.2 \%$ & $26-28 \%$ & - & $31.5-37 \%$ \\
\hline Other & NR & $\overline{\mathrm{NR}}$ & NR & $9 \%-42 \%$ & $20-40 \%$ & - & $16-18 \%$ \\
\hline
\end{tabular}

UPDRS: Unified Parkinson Disease Rating Scale; NR: Not reported. 
Table 3. Efficacy results. Change in outcomes from baseline to end point

\begin{tabular}{|c|c|c|c|c|}
\hline \multirow[b]{2}{*}{ Study } & \multicolumn{2}{|c|}{$\begin{array}{l}\text { ime spent in the OFF stat } \\
\text { Mean Change }\end{array}$} & \multicolumn{2}{|c|}{$\begin{array}{c}\text { UPDRS subscale III } \\
\text { On state }\end{array}$} \\
\hline & $\%$ & Hours & LS mean change LS m & $\begin{array}{l}\text { mean difference } \\
\text { from placebo }\end{array}$ \\
\hline \multicolumn{5}{|l|}{ Hauser 2003} \\
\hline stradefylline $5 / 10 / 20 \mathrm{mg} / \mathrm{da}$. & $-8.2 *$ & $-1.4^{*}$ & NR & NR \\
\hline stradefylline $5 / 10 / 20 \mathrm{mg} / \mathrm{da}$ & $-6.1 *$ & $-1.1^{*}$ & NR & NR \\
\hline Placebo & 2.2 & 0.5 & & \\
\hline \multicolumn{5}{|l|}{ LeWitt 2008} \\
\hline Istradefylline $40 \mathrm{mg} /$ day & $-10.81 *$ & $-1.79 *$ & -0.4 & NR \\
\hline Placebo & -4.04 & -0.64 & -0.2 & \\
\hline \multicolumn{5}{|l|}{ Hauser 2008} \\
\hline Istradefylline $20 \mathrm{mg} /$ day & $-9.3^{*}$ & $-1.6^{*}$ & NR & NR \\
\hline Placebo & -5.0 & -0.9 & NR & \\
\hline \multicolumn{5}{|l|}{ Stacy 2008} \\
\hline Istradefylline $20 \mathrm{mg} /$ day & $-7.83 *$ & -1.24 & NR & -0.30 \\
\hline Istradefylline $60 \mathrm{mg} /$ day & $-7.96 *$ & -1.37 & NR & -0.87 \\
\hline Placebo & -3.47 & -0.60 & NR & \\
\hline \multicolumn{5}{|l|}{ Fernández 2010} \\
\hline Istradefylline $40 \mathrm{mg} /$ day & NR & NR & -0.74 & -1.11 \\
\hline Placebo & NR & NR & 0.36 & \\
\hline \multicolumn{5}{|l|}{ Mizuno 2010} \\
\hline Istradefylline $20 \mathrm{mg} /$ day & NR & $-1.31 *$ & $-1.31 *$ & $-2.0^{*}$ \\
\hline Istradefylline $40 \mathrm{mg} /$ day & NR & $-1.58^{*}$ & $-1.58^{*}$ & $-2.0^{*}$ \\
\hline Placebo & NR & -0.66 & -0.66 & \\
\hline
\end{tabular}


Table 4. Most frequent adverse events possible or probably related to study reported by $5 \%$ or more subjects in either treatment group, by system organ class and preferred term (safety population)

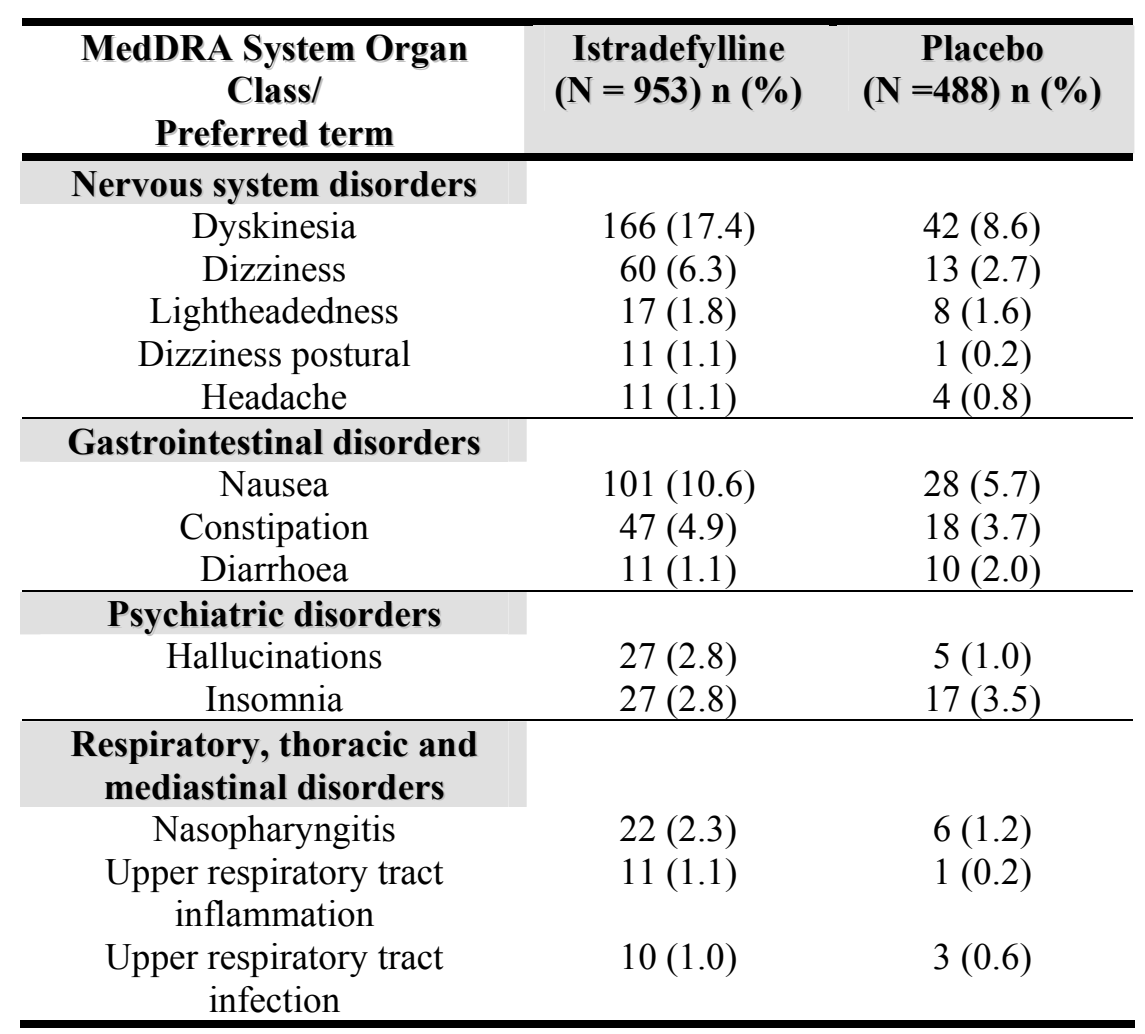


Table 5. Ongoing clinical trials testing drugs acting on $A_{2} R$ registered with www.ClinicalTrials.gov (on March 30, 2011).

\begin{tabular}{|c|c|c|c|c|c|c|c|}
\hline ID & Sponsor & Status & $\begin{array}{c}\text { Design/ } \\
\text { Clinical } \\
\text { trial } \\
\text { Phase } \\
\end{array}$ & $\begin{array}{c}\text { Experimental } \\
\text { Drug / } \\
\text { Duration }\end{array}$ & Control & $\begin{array}{c}\text { Size } \\
\text { (n) }\end{array}$ & Condition PD \\
\hline NCT00955526 & $\begin{array}{l}\text { Kyowa } \\
\text { Hakko } \\
\text { Kirin }\end{array}$ & $\begin{array}{c}\text { A } \\
(\text { ESCD } \\
\text { May 2011) }\end{array}$ & $\begin{array}{l}\text { DB RCT } \\
\text { Phase III }\end{array}$ & $\begin{array}{l}\bullet \text { Istradefylline } \\
20 \text { and } 40 \\
\mathrm{mg} / \text { day / 12- } \\
\text { weeks }\end{array}$ & -Placebo & 360 & $\begin{array}{l}\text { UKPDS step 1-2 } \\
\text { MHYS stages 2-4 } \\
\text { off state } \\
\text { On LD/DC 1year }\end{array}$ \\
\hline NCT00957203 & $\begin{array}{l}\text { Kyowa } \\
\text { Hakko } \\
\text { Kirin }\end{array}$ & $\begin{array}{c}\text { A } \\
\text { (ESCD } \\
\text { June 2012) }\end{array}$ & $\begin{array}{l}\text { OL } \\
\text { NRCT } \\
\text { SG } \\
\text { Phase III }\end{array}$ & $\begin{array}{l}\bullet \text { Istradefylline } \\
20 \text { and } 40 \\
\mathrm{mg} / \text { day / long- } \\
\text { term }\end{array}$ & - & 150 & $\begin{array}{l}\text { Advanced PD } \\
\text { treated with LD }\end{array}$ \\
\hline NCT01155479 & $\begin{array}{c}\text { Schering- } \\
\text { Plough } \\
\text { (P05664AM2) }\end{array}$ & $\begin{array}{c}\text { R } \\
\text { (June } \\
\text { 2013) }\end{array}$ & $\begin{array}{l}\text { DB RCT } \\
\text { Phase III }\end{array}$ & $\begin{array}{l}\bullet \text { Preladenant } \\
4,10,20 \mathrm{mg} \\
\text { daily / } \\
52 \text { weeks }\end{array}$ & $\begin{array}{l}\text {-Placebo } \\
\text { (26 weeks) } \\
\text { and after } \\
\text { Preladenant } \\
\text { (26 weeks) } \\
\text {-Rasagiline } \\
\text { 1mg daily }\end{array}$ & 1,000 & $\begin{array}{l}-\mathrm{PD}<5 \text { years } \\
\text {-UKPDS Part III } \\
\geq 10 \\
\text {-HYS stage } \leq 3\end{array}$ \\
\hline NCT01227265 & $\begin{array}{c}\text { Schering- } \\
\text { Plough } \\
\text { (P07037AM1) }\end{array}$ & $\begin{array}{c}\mathrm{R} \\
\text { (September } \\
\text { 2012) }\end{array}$ & $\begin{array}{l}\text { DB RCT } \\
\text { Phase III }\end{array}$ & $\begin{array}{l}\bullet \text { Preladenant } \\
4,10,20 \mathrm{mg} \\
\text { daily/ } \\
12 \text { weeks }\end{array}$ & -Placebo & 450 & $\begin{array}{l}\text {-On LD } \geq 1 \text { year } \\
\text {-HYS } 2.5-4 \text { "on" } \\
\text { state } \\
-\geq 2 \text { hours day } \\
\text { "off" time }\end{array}$ \\
\hline NCT01155466 & $\begin{array}{c}\text { Schering- } \\
\text { Plough } \\
\text { (P04938AM3) }\end{array}$ & $\begin{array}{c}\mathrm{R} \\
\text { (February } \\
\text { 2013) }\end{array}$ & $\begin{array}{l}\text { DB RCT } \\
\text { Phase III }\end{array}$ & $\begin{array}{l}\bullet \text { Preladenant } \\
4,10,20 \mathrm{mg} \\
\text { daily/ } \\
12 \text { weeks }\end{array}$ & $\begin{array}{l}\text { - Placebo } \\
\text { - Rasigiline } \\
\text { 1mg daily }\end{array}$ & 750 & $\begin{array}{l}\text {-On LD } \geq 1 \text { year } \\
\text {-HYS } 2.5-4 \text { "on" } \\
\text { state } \\
-\geq 2 \text { hours day } \\
\text { "off" time }\end{array}$ \\
\hline NCT01294800 & $\begin{array}{l}\text { Schering- } \\
\text { Plough } \\
\text { (P06402) }\end{array}$ & $\begin{array}{c}\text { R } \\
\text { (June } \\
\text { 2013) }\end{array}$ & $\begin{array}{l}\text { DB RCT } \\
\text { Phase III }\end{array}$ & $\begin{array}{l}\bullet \text { Preladenant } \\
4,10,20 \mathrm{mg} \\
\text { daily/ } \\
12 \text { weeks }\end{array}$ & - Placebo & 440 & $\begin{array}{l}\text {-On LD } \geq 1 \text { year } \\
\text {-HYS } 2.5-4 \text { "on" } \\
\text { state } \\
-\geq 2 \text { hours day } \\
\text { "off" time }\end{array}$ \\
\hline NCT01215227 & $\begin{array}{c}\text { Schering- } \\
\text { Plough } \\
\text { (P06153AM1) }\end{array}$ & $\begin{array}{c}\text { R } \\
\text { (January } \\
\text { 2013) }\end{array}$ & $\begin{array}{l}\text { DB RCT } \\
\text { Phase III }\end{array}$ & $\begin{array}{l}\bullet \text { Preladenant } \\
\text { 4, 10, } 20 \mathrm{mg} \\
\text { daily/ } \\
40 \text { weeks }\end{array}$ & $\begin{array}{l}\text { - Placebo } \\
\text { - Rasigiline } \\
\text { 1mg daily }\end{array}$ & 750 & $\begin{array}{l}\text {-On LD } \geq 1 \text { year } \\
\text {-HYS } 2.5-4 \text { "on" } \\
\text { state } \\
-\geq 2 \text { hours day } \\
\text { "off" time }\end{array}$ \\
\hline NCT00406029 & $\begin{array}{c}\text { Schering- } \\
\text { Plough } \\
\text { (P04501AM3) }\end{array}$ & $\mathrm{C}$ & $\begin{array}{l}\text { DB RCT } \\
\text { Phase II }\end{array}$ & $\begin{array}{l}\bullet \text { Preladenant } \\
2,4,10 \mathrm{mg} \\
\text { daily/ } \\
12 \text { weeks }\end{array}$ & - Placebo & 200 & $\begin{array}{l}\text { PD moderate to } \\
\text { severe } \geq 5 \text { years }\end{array}$ \\
\hline NCT00537017 & $\begin{array}{c}\text { Schering- } \\
\text { Plough } \\
\text { (P05175AM1) }\end{array}$ & $\mathrm{C}$ & $\begin{array}{l}\text { OL, SG } \\
\text { NRCT } \\
\text { Phase II }\end{array}$ & $\begin{array}{l}\bullet \text { Preladenant } \\
10 \text { mg daily/ } \\
12 \text { weeks }\end{array}$ & - & 200 & $\begin{array}{l}\text { PD moderate to } \\
\text { severe } \geq 5 \text { years }\end{array}$ \\
\hline
\end{tabular}




\begin{tabular}{|c|c|c|c|c|c|c|c|}
\hline NCT01323855 & $\begin{array}{c}\text { Schering- } \\
\text { Plough } \\
\text { (P06512AM1) }\end{array}$ & $\begin{array}{c}\text { NYR } \\
\text { (September } \\
\text { 2011) } \\
\end{array}$ & $\begin{array}{l}\text { OL, SG } \\
\text { NRCT } \\
\text { Phase I }\end{array}$ & $\begin{array}{l}\text {-Preladenant } \\
5 \text { mg daily/ } \\
72 \text { hours }\end{array}$ & - & 54 & $\begin{array}{l}\text { Mild to severe } \\
\text { chronic renal } \\
\text { impairment }\end{array}$ \\
\hline NCT00845000 & $\begin{array}{c}\text { Schering- } \\
\text { Plough } \\
\text { (P05550AM2) }\end{array}$ & $\mathrm{C}$ & $\begin{array}{l}\text { SB RCT } \\
\text { Phase II }\end{array}$ & $\begin{array}{l}\bullet \text { Preladenant } \\
10 \text { or } 100 \mathrm{mg} \\
\text { daily and LD } \\
\text { intravenous } \\
\text { and oral } \\
\text { carbidopa/ } 5 \\
\text { hours }\end{array}$ & - Placebo & 18 & $\begin{array}{l}\text {-On LD } \geq 1 \text { year } \\
\text { - Motor } \\
\text { fluctuations and } \\
\text { UPDRS } \\
20 \% \text { improvement } \\
\text { when "on" } \\
\text { - Dyskinesia } \\
\text { when "on" } \geq 2 \text { on } \\
\text { scale }(0-4)\end{array}$ \\
\hline NCT00442780 & Biogen IDEC & $\mathrm{C}$ & $\begin{array}{l}\text { DB RCT } \\
\text { Phase II }\end{array}$ & $\begin{array}{l}\bullet \text { BIIB014 } \\
\text { dose } \\
\text { escalation /NR }\end{array}$ & Placebo & 36 & $\begin{array}{l}\text { PD } \leq 5 \text { years } \\
\text { MHYS stages } 1- \\
2.5\end{array}$ \\
\hline NCT00438607 & Biogen IDEC & $\mathrm{C}$ & $\begin{array}{l}\text { DB RCT } \\
\text { Phase II }\end{array}$ & $\begin{array}{l}\bullet \text { BIIB014 } \\
\text { escalation /NR }\end{array}$ & Placebo & 83 & $\begin{array}{l}\text { MHYS stages 2-4 } \\
\text { off state }\end{array}$ \\
\hline NCT00451815 & Biogen IDEC & W & $\begin{array}{l}\text { DB RCT } \\
\text { Phase II }\end{array}$ & $\begin{array}{l}\bullet \text { BIIB014 } \\
10,30,100, \\
300 \mathrm{mg} \text { once } \\
\text { daily }\end{array}$ & Placebo & NR & MHYS stages 1-3 \\
\hline NCT01283594 & $\begin{array}{c}\text { Synosia } \\
\text { Therapeutics }\end{array}$ & $\begin{array}{l}\text { NYR } \\
\text { (August } \\
2012 \text { ) }\end{array}$ & $\begin{array}{c}\text { DB RCT } \\
\text { Phase } \\
\text { II/III }\end{array}$ & $\begin{array}{l}\bullet \text { SYN115 60, } \\
120,180,140 \\
\text { mg / NR }\end{array}$ & Placebo & 400 & $\begin{array}{l}\text { PD with good } \\
\text { response LD }\end{array}$ \\
\hline NCT00605553 & $\begin{array}{c}\text { Synosia } \\
\text { Therapeutics }\end{array}$ & $\mathrm{C}$ & $\begin{array}{c}\text { DB } \\
\text { Crossover } \\
\text { RCT } \\
\text { Phase II }\end{array}$ & $\begin{array}{l}\bullet \text { SYN115 } \\
20,60 \mathrm{mg} \\
\text { daily / 1 week }\end{array}$ & Placebo & 30 & MHYS stages 1-3 \\
\hline
\end{tabular}

ID: ClinicalTrials.gov Identifier; Size (n): estimated enrolment of the number of patients; PD: Parkinson

Disease; Status: C (Completed) the study has been completed, A (Active) the study is ongoing, but not recruiting participants, $\mathrm{R}$ (Recruiting) the study is currently recruiting participants, W (Withdrawn) the study has been withdrawn prior enrollment of patients, NYT The study is not yet open for participant recruitment.; ESCD: Estimated Study Completion Data; DB: Double blind masking; OL: Open label masking; SB: Single blind masking; SG: Single group; RCT: randomised clinical trial; NRCT: nonrandomised clinical trial; UKPDS: UK Parkinson's Disease Society (UKPDS) criteria for PD; HYS: Hoehn and Yahr Scale; MHYS: Modified Hoehn and Yahr Scale: LD: L-DOPA; NR: Non reported. 


\section{REFERENCES}

[1] Newby, A.C. Adenosine and the concept of "retaliatory metabolites". Trends Biochem. Sci., 1984, 9, 42-44.

[2] Ferre, S.; Ciruela, F.; Quiroz, C.; Lujan, R.; Popoli, P.; Cunha, R.A.; Agnati, L.F.; Fuxe, K.; Woods, A.S.; Lluis, C.; Franco, R. Adenosine receptor heteromers and their integrative role in striatal function. ScientificWorldJournal, 2007, 7, 74-85.

[3] Latini, S.; Pedata, F. Adenosine in the central nervous system: Release mechanisms and extracellular concentrations. J. Neurochem., 2001, 79, 463-484.

[4] Snyder, S.H. Adenosine as a neuromodulator. Annu. Rev. Neurosci., 1985, 8, 103 124.

[5] Ferre, S.; Fuxe, K. Adenosine as a volume transmission signal. A feedback detector of neuronal activation. Prog. Brain Res., 2000, 125, 353-361.

[6] Fredholm, B.B. Purinoceptors in the nervous system. Pharmacol. Toxicol., 1995, $76,228-239$.

[7] Klyuch, B.P.; Richardson, M.J.; Dale, N.; Wall, M.J. The dynamics of single spike-evoked adenosine release in the cerebellum. J. Physiol., 2011, 589, 283295.

[8] Dunwiddie, T.V.; Masino, S.A. The role and regulation of adenosine in the central nervous system. Annu. Rev. Neurosci., 2001, 24, 31-55.

[9] Ciruela, F.; Casado, V.; Rodrigues, R.J.; Lujan, R.; Burgueno, J.; Canals, M.; Borycz, J.; Rebola, N.; Goldberg, S.R.; Mallol, J.; Cortes, A.; Canela, E.I.; LopezGimenez, J.F.; Milligan, G.; Lluis, C.; Cunha, R.A.; Ferre, S.; Franco, R. 
Presynaptic control of striatal glutamatergic neurotransmission by adenosine A1A2A receptor heteromers. J. Neurosci., 2006, 26, 2080-2087.

[10] Ciruela, F.; Gomez-Soler, M.; Guidolin, D.; Borroto-Escuela, D.O.; Agnati, L.F.; Fuxe, K.; Fernandez-Duenas, V. Adenosine receptor containing oligomers: Their role in the control of dopamine and glutamate neurotransmission in the brain. Biochim. Biophys. Acta, 2011, 1808, 1245-1255.

[11] Cabello, N.; Gandia, J.; Bertarelli, D.C.; Watanabe, M.; Lluis, C.; Franco, R.; Ferre, S.; Lujan, R.; Ciruela, F. Metabotropic glutamate type 5, dopamine $\mathrm{D}(2)$ and adenosine $\mathrm{A}(2 \mathrm{a})$ receptors form higher-order oligomers in living cells. $J$. Neurochem., 2009, 109, 1497-1507.

[12] Hely, M.A.; Morris, J.G.; Reid, W.G.; Trafficante, R. Sydney multicenter study of parkinson's disease: Non-L-dopa-responsive problems dominate at 15 years. Mov. Disord., 2005, 20, 190-199.

[13] Lang, A.E.; Lozano, A.M. Parkinson's disease. first of two parts. N. Engl. J. Med., 1998, 339, 1044-1053.

[14] Braak, H.; Del Tredici, K.; Rub, U.; de Vos, R.A.; Jansen Steur, E.N.; Braak, E. Staging of brain pathology related to sporadic parkinson's disease. Neurobiol. Aging, 2003, 24, 197-211.

[15] Zarow, C.; Lyness, S.A.; Mortimer, J.A.; Chui, H.C. Neuronal loss is greater in the locus coeruleus than nucleus basalis and substantia nigra in alzheimer and parkinson diseases. Arch. Neurol., 2003, 60, 337-341.

[16] Spillantini, M.G.; Schmidt, M.L.; Lee, V.M.; Trojanowski, J.Q.; Jakes, R.; Goedert, M. Alpha-synuclein in lewy bodies. Nature, 1997, 388, 839-840. 
[17] Reiner, A.; Medina, L.; Haber, S.N. The distribution of dynorphinergic terminals in striatal target regions in comparison to the distribution of substance Pcontaining and enkephalinergic terminals in monkeys and humans. Neuroscience, 1999, 88, 775-793.

[18] Steiner, H.; Gerfen, C.R. Role of dynorphin and enkephalin in the regulation of striatal output pathways and behavior. Exp. Brain Res., 1998, 123, 60-76.

[19] Perreault, M.L.; Hasbi, A.; Alijaniaram, M.; Fan, T.; Varghese, G.; Fletcher, P.J.; Seeman, P.; O'Dowd, B.F.; George, S.R. The dopamine D1-D2 receptor heteromer localizes in dynorphin/enkephalin neurons: Increased high affinity state following amphetamine and in schizophrenia. J. Biol. Chem., 2010, 285, 3662536634.

[20] Bornstein, A.M.; Daw, N.D. Multiplicity of control in the basal ganglia: Computational roles of striatal subregions. Curr. Opin. Neurobiol., 2011, .

[21] Fuxe, K.; Marcellino, D.; Borroto-Escuela, D.O.; Guescini, M.; FernandezDuenas, V.; Tanganelli, S.; Rivera, A.; Ciruela, F.; Agnati, L.F. Adenosinedopamine interactions in the pathophysiology and treatment of CNS disorders. CNS Neurosci. Ther., 2010, 16, e18-42.

[22] Cotzias, G.C.; Van Woert, M.H.; Schiffer, L.M. Aromatic amino acids and modification of parkinsonism. N. Engl. J. Med., 1967, 276, 374-379.

[23] Olanow, C.W. MAO-B inhibitors in parkinson's disease. Adv. Neurol., 1993, 60, 666-671.

[24] Piccini, P.; Brooks, D.J.; Korpela, K.; Pavese, N.; Karlsson, M.; Gordin, A. The catechol-O-methyltransferase (COMT) inhibitor entacapone enhances the 
pharmacokinetic and clinical response to sinemet CR in parkinson's disease. $J$. Neurol. Neurosurg. Psychiatry., 2000, 68, 589-594.

[25] Olanow, C.W.; Stocchi, F. COMT inhibitors in parkinson's disease: Can they prevent and/or reverse levodopa-induced motor complications? Neurology, 2004, 62, S72-81.

[26] Schapira, A.H.; Bezard, E.; Brotchie, J.; Calon, F.; Collingridge, G.L.; Ferger, B.; Hengerer, B.; Hirsch, E.; Jenner, P.; Le Novere, N.; Obeso, J.A.; Schwarzschild, M.A.; Spampinato, U.; Davidai, G. Novel pharmacological targets for the treatment of parkinson's disease. Nat. Rev. Drug Discov., 2006, 5, 845-854.

[27] Rascol, O.; Brooks, D.J.; Korczyn, A.D.; De Deyn, P.P.; Clarke, C.E.; Lang, A.E. A five-year study of the incidence of dyskinesia in patients with early parkinson's disease who were treated with ropinirole or levodopa. 056 study group. $N$. Engl. J. Med., 2000, 342, 1484-1491.

[28] Meyer, A.K.; Maisel, M.; Hermann, A.; Stirl, K.; Storch, A. Restorative approaches in parkinson's disease: Which cell type wins the race? J. Neurol. Sci., 2010, 289, 93-103.

[29] Hermann, A.; Gerlach, M.; Schwarz, J.; Storch, A. Neurorestoration in parkinson's disease by cell replacement and endogenous regeneration. Expert Opin. Biol. Ther., 2004, 4, 131-143.

[30] Popoli, P.; Pezzola, A.; Torvinen, M.; Reggio, R.; Pintor, A.; Scarchilli, L.; Fuxe, K.; Ferre, S. The selective mGlu(5) receptor agonist CHPG inhibits quinpiroleinduced turning in 6-hydroxydopamine-lesioned rats and modulates the binding 
characteristics of dopamine $\mathrm{D}(2)$ receptors in the rat striatum: Interactions with adenosine A(2a) receptors. Neuropsychopharmacology, 2001, 25, 505-513.

[31] Carriba, P.; Navarro, G.; Ciruela, F.; Ferre, S.; Casado, V.; Agnati, L.; Cortes, A.; Mallol, J.; Fuxe, K.; Canela, E.I.; Lluis, C.; Franco, R. Detection of heteromerization of more than two proteins by sequential BRET-FRET. Nat. Methods, 2008, 5, 727-733.

[32] Ferre, S.; Quiroz, C.; Woods, A.S.; Cunha, R.; Popoli, P.; Ciruela, F.; Lluis, C.; Franco, R.; Azdad, K.; Schiffmann, S.N. An update on adenosine A2A-dopamine D2 receptor interactions: Implications for the function of $\mathrm{G}$ protein-coupled receptors. Curr. Pharm. Des., 2008, 14, 1468-1474.

[33] Schwarzschild, M.A.; Agnati, L.; Fuxe, K.; Chen, J.F.; Morelli, M. Targeting adenosine A2A receptors in parkinson's disease. Trends Neurosci., 2006, 29, 647654.

[34] Jenner, P. Istradefylline, a novel adenosine A2A receptor antagonist, for the treatment of parkinson's disease. Expert Opin. Investig. Drugs, 2005, 14, 729-738.

[35] LeWitt, P.A.; Guttman, M.; Tetrud, J.W.; Tuite, P.J.; Mori, A.; Chaikin, P.; Sussman, N.M.; 6002-US-005 Study Group. Adenosine A2A receptor antagonist istradefylline (KW-6002) reduces "off" time in parkinson's disease: A doubleblind, randomized, multicenter clinical trial (6002-US-005). Ann. Neurol., 2008, 63, 295-302.

[36] Antonelli, T.; Fuxe, K.; Agnati, L.; Mazzoni, E.; Tanganelli, S.; Tomasini, M.C.; Ferraro, L. Experimental studies and theoretical aspects on A2A/D2 receptor 
interactions in a model of parkinson's disease. relevance for L-dopa induced dyskinesias. J. Neurol. Sci., 2006, 248, 16-22.

[37] Calon, F.; Dridi, M.; Hornykiewicz, O.; Bedard, P.J.; Rajput, A.H.; Di Paolo, T. Increased adenosine $\mathrm{A} 2 \mathrm{~A}$ receptors in the brain of parkinson's disease patients with dyskinesias. Brain, 2004, 127, 1075-1084.

[38] Bibbiani, F.; Oh, J.D.; Petzer, J.P.; Castagnoli, N.,Jr; Chen, J.F.; Schwarzschild, M.A.; Chase, T.N. A2A antagonist prevents dopamine agonist-induced motor complications in animal models of parkinson's disease. Exp. Neurol., 2003, 184, 285-294.

[39] Frau, L.; Borsini, F.; Wardas, J.; Khairnar, A.S.; Schintu, N.; Morelli, M. Neuroprotective and anti-inflammatory effects of the adenosine $\mathrm{A}(2 \mathrm{~A})$ receptor antagonist ST1535 in a MPTP mouse model of parkinson's disease. Synapse, 2011, 65, 181-188.

[40] Ramlackhansingh, A.F.; Bose, S.K.; Ahmed, I.; Turkheimer, F.E.; Pavese, N.; Brooks, D.J. Adenosine 2A receptor availability in dyskinetic and nondyskinetic patients with parkinson disease. Neurology, 2011, 76, 1811-1816.

[41] Chen, J.F.; Huang, Z.; Ma, J.; Zhu, J.; Moratalla, R.; Standaert, D.; Moskowitz, M.A.; Fink, J.S.; Schwarzschild, M.A. A(2A) adenosine receptor deficiency attenuates brain injury induced by transient focal ischemia in mice. J. Neurosci., 1999, 19, 9192-9200.

[42] Dall'Igna, O.P.; Porciuncula, L.O.; Souza, D.O.; Cunha, R.A.; Lara, D.R. Neuroprotection by caffeine and adenosine A2A receptor blockade of betaamyloid neurotoxicity. Br. J. Pharmacol., 2003, 138, 1207-1209. 
[43] Melani, A.; Pantoni, L.; Bordoni, F.; Gianfriddo, M.; Bianchi, L.; Vannucchi, M.G.; Bertorelli, R.; Monopoli, A.; Pedata, F. The selective A2A receptor antagonist SCH 58261 reduces striatal transmitter outflow, turning behavior and ischemic brain damage induced by permanent focal ischemia in the rat. Brain Res., 2003, 959, 243-250.

[44] Fink, J.S.; Kalda, A.; Ryu, H.; Stack, E.C.; Schwarzschild, M.A.; Chen, J.F.; Ferrante, R.J. Genetic and pharmacological inactivation of the adenosine A2A receptor attenuates 3-nitropropionic acid-induced striatal damage. J. Neurochem., 2004, 88, 538-544.

[45] Carta, A.R.; Kachroo, A.; Schintu, N.; Xu, K.; Schwarzschild, M.A.; Wardas, J.; Morelli, M. Inactivation of neuronal forebrain A receptors protects dopaminergic neurons in a mouse model of parkinson's disease. J. Neurochem., 2009, 111, 1478-1489.

[46] Fox, S.H.; Brotchie, J.M.; Lang, A.E. Non-dopaminergic treatments in development for parkinson's disease. Lancet Neurol., 2008, 7, 927-938.

[47] Morelli, M.; Carta, A.R.; Jenner, P. Adenosine A2A receptors and parkinson's disease. Handb. Exp. Pharmacol., 2009, (193), 589-615.

[48] Simola, N.; Morelli, M.; Pinna, A. Adenosine A2A receptor antagonists and parkinson's disease: State of the art and future directions. Curr. Pharm. Des., 2008, $14,1475-1489$.

[49] Jenner, P.; Mori, A.; Hauser, R.; Morelli, M.; Fredholm, B.B.; Chen, J.F. Adenosine, adenosine A 2A antagonists, and parkinson's disease. Parkinsonism Relat. Disord., 2009, 15, 406-413. 
[50] Cieslak, M.; Komoszynski, M.; Wojtczak, A. Adenosine A(2A) receptors in parkinson's disease treatment. Purinergic Signal., 2008, 4, 305-312.

[51] Pinna, A. Novel investigational adenosine A2A receptor antagonists for parkinson's disease. Expert Opin. Investig. Drugs, 2009, 18, 1619-1631.

[52] Muller, T. New small molecules for the treatment of parkinson's disease. Expert Opin. Investig. Drugs, 2010, 19, 1077-1086.

[53] Lundblad, M.; Vaudano, E.; Cenci, M.A. Cellular and behavioural effects of the adenosine A2a receptor antagonist KW-6002 in a rat model of 1-DOPA-induced dyskinesia. J. Neurochem., 2003, 84, 1398-1410.

[54] Pierri, M.; Vaudano, E.; Sager, T.; Englund, U. KW-6002 protects from MPTP induced dopaminergic toxicity in the mouse. Neuropharmacology, 2005, 48, 517524.

[55] Koga, K.; Kurokawa, M.; Ochi, M.; Nakamura, J.; Kuwana, Y. Adenosine A(2A) receptor antagonists KF17837 and KW-6002 potentiate rotation induced by dopaminergic drugs in hemi-parkinsonian rats. Eur. J. Pharmacol., 2000, 408, 249-255.

[56] Kanda, T.; Jackson, M.J.; Smith, L.A.; Pearce, R.K.; Nakamura, J.; Kase, H.; Kuwana, Y.; Jenner, P. Adenosine A2A antagonist: A novel antiparkinsonian agent that does not provoke dyskinesia in parkinsonian monkeys. Ann. Neurol., 1998, 43, 507-513.

[57] Kanda, T.; Jackson, M.J.; Smith, L.A.; Pearce, R.K.; Nakamura, J.; Kase, H.; Kuwana, Y.; Jenner, P. Combined use of the adenosine A(2A) antagonist KW6002 with L-DOPA or with selective D1 or D2 dopamine agonists increases 
antiparkinsonian activity but not dyskinesia in MPTP-treated monkeys. Exp. Neurol., 2000, 162, 321-327.

[58] Grondin, R.; Bedard, P.J.; Hadj Tahar, A.; Gregoire, L.; Mori, A.; Kase, H. Antiparkinsonian effect of a new selective adenosine A2A receptor antagonist in MPTP-treated monkeys. Neurology, 1999, 52, 1673-1677.

[59] Hauser, R.A.; Schwarzschild, M.A. Adenosine A2A receptor antagonists for parkinson's disease: Rationale, therapeutic potential and clinical experience. Drugs Aging, 2005, 22, 471-482.

[60] Knebel, W.; Rao, N.; Uchimura, T.; Mori, A.; Fisher, J.; Gastonguay, M.R.; Chaikin, P. Population pharmacokinetic analysis of istradefylline in healthy subjects and in patients with parkinson's disease. J. Clin. Pharmacol., 2011, 51, $40-52$.

[61] Bara-Jimenez, W.; Sherzai, A.; Dimitrova, T.; Favit, A.; Bibbiani, F.; Gillespie, M.; Morris, M.J.; Mouradian, M.M.; Chase, T.N. Adenosine A(2A) receptor antagonist treatment of parkinson's disease. Neurology, 2003, 61, 293-296.

[62] Hauser, R.A.; Hubble, J.P.; Truong, D.D.; Istradefylline US-001 Study Group. Randomized trial of the adenosine $\mathrm{A}(2 \mathrm{~A})$ receptor antagonist istradefylline in advanced PD. Neurology, 2003, 61, 297-303.

[63] Hauser, R.A.; Shulman, L.M.; Trugman, J.M.; Roberts, J.W.; Mori, A.; Ballerini, R.; Sussman, N.M.; Istradefylline 6002-US-013 Study Group. Study of istradefylline in patients with parkinson's disease on levodopa with motor fluctuations. Mov. Disord., 2008, 23, 2177-2185. 
[64] Stacy, M.; Silver, D.; Mendis, T.; Sutton, J.; Mori, A.; Chaikin, P.; Sussman, N.M. A 12-week, placebo-controlled study (6002-US-006) of istradefylline in parkinson disease. Neurology, 2008, 70, 2233-2240.

[65] Mizuno, Y.; Hasegawa, K.; Kondo, T.; Kuno, S.; Yamamoto, M.; Japanese Istradefylline Study Group. Clinical efficacy of istradefylline (KW-6002) in parkinson's disease: A randomized, controlled study. Mov. Disord., 2010, 25, 1437-1443.

[66] Fernandez, H.H.; Greeley, D.R.; Zweig, R.M.; Wojcieszek, J.; Mori, A.; Sussman, N.M.; 6002-US-051 Study Group. Istradefylline as monotherapy for parkinson disease: Results of the 6002-US-051 trial. Parkinsonism Relat. Disord., 2010, 16, $16-20$

[67] Hauser, R.A.; Cantillon, M.; Pourcher, E.; Micheli, F.; Mok, V.; Onofrj, M.; Huyck, S.; Wolski, K. Preladenant in patients with parkinson's disease and motor fluctuations: A phase 2, double-blind, randomised trial. Lancet Neurol., 2011, 10, 221-229. 


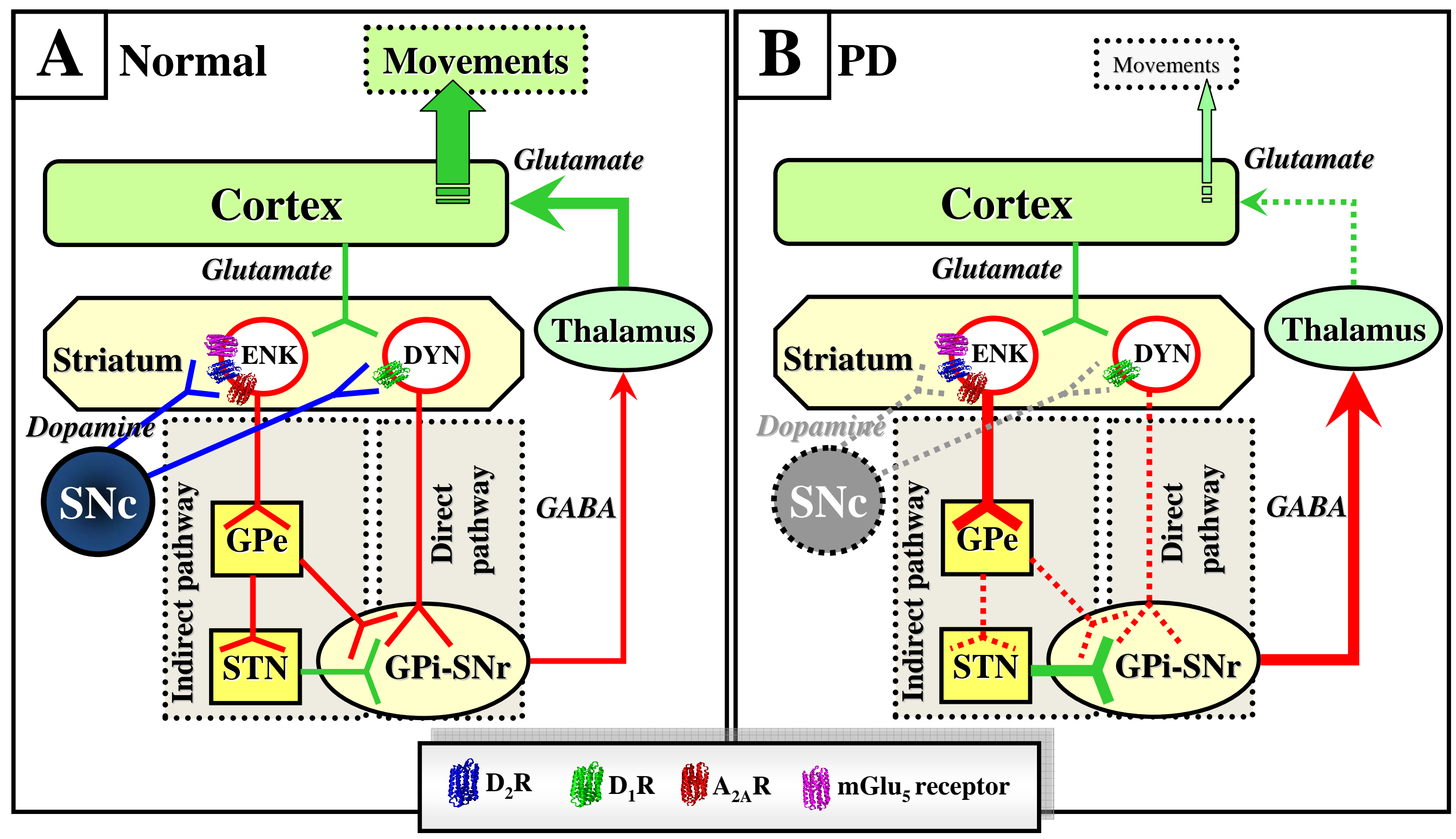

